\title{
Innovative Production of Polyvinychloride on the Basis of Vertical Integration of Business and Cluster Organisation
}

\author{
Irina Kudryashova ${ }^{1}$, Natalia Zakharova ${ }^{2}$, and Evgeniy Kharlampenkov ${ }^{3}$ \\ ${ }^{1}$ Kemerovo institute (branch) of the Russian Plekhanov Economic University, Administration, 650992 \\ Kemerovo, 39 Kuznetskiy av., Russia \\ ${ }^{2}$ Plekhanov Russian University of Economics, Department of the World Economy, 117997, \\ Moscow,36 Stremyanny lane, Russia \\ ${ }^{3}$ Kemerovo institute (branch) of the Russian Plekhanov Economic University, Department of \\ Commercial Affair, 650992 Kemerovo, 39 Kuznetskiy av., Russia
}

\begin{abstract}
The paper presents the results of the research of the world and Russian market of polyvinyl chloride (PVC), a comparative assessment is made and the similarities and differences of these segments at the present have been identified. The theoretical possibility of considerable prospects of the development of domestic production of PVC is justified, ensure that it can achieve import substitution and export substitution of this product in Russia. Based on the theory of value chains and cluster organization of the enterprises of coal and chemical industries, ferrous metallurgy and other enterprises of Kuzbass have been proposed new technological solutions for the production of PVC, taking into account regional features of naturalresource base and capacity of national and world markets. It is established that the organization of production of PVC, using coal chemistry technology can be a promising growth point for the business of the Kemerovo region, will help to diversify the coal industry, to expand its product structure and export potential of the region, increase its competitiveness.
\end{abstract}

\section{Introduction}

Kuzbass at the turn of XX - XXI centuries moved into the category of old coal regions experiencing pressure from newly developing coal basins located in Yakutia and Tuva, having rich deposits of coking and energy coal. In this case the logistics component of delivery of coal to the countries of South-East Asia and Japan for these fields, given the proximity of BAM and the ports of Primorye, significantly reduces the competitiveness of Kuznetsk coal. In this case the logistics component of delivery of coal to the countries of South-East Asia and Japan for these fields, given the proximity of BAM and the ports of Primorye, significantly reduces the competitiveness of Kuznetsk coal. Despite the fact that the share of Kuzbass in the coal export of Russia at the moment remains high at $77 \%$, and coking grades of $80 \%$, the pressure of new coal basins continues to increase.. It is worth noting that coal is transforming from the fastest growing energy source (increase in world consumption in the period 2000-2013 amounted to, on average, $3.8 \%$ per year) to the fuel with 
the lowest development index of consumption (about $0.8 \%$ per year in the period 20152035.). It makes Kuzbass enterprises to search new markets and to solve the issues for creation of manufactures of processing of coal in place, allowing to obtain a product with a higher added value, using the cluster approach, cooperation of industrial relations, integrative approaches of interaction. Significant technological capabilities for the further development of coal in the region and in Russia are prompted thanks to the conversion of coal in non-fuel products (chemical intermediates, compounds, carbon materials), the creation and production of which determines the level of technological sovereignty of the country and readiness for potential changes in the global energy balance and structure of consumption of hydrocarbon resources. Coal, as the experience of a number of countries, primarily China, shows, can be quite competitive raw material for the production of many chemical products. The higher the degree of processing of coal and the level of high-tech product produced from coal, the lower component of the logistics (mainly transport) and the more efficient becomes the process of coal production. If coke tariff rate per 1 ton is $29 \%$ of its value, then PVC - 9\%. Taking into account the capacity of coal-chemical cluster of the Kemerovo region, the project of PVC production is quite promising, feasible and costeffective. While the values of non-fuel products, conversion of coal - chemical intermediates and precursors that are in demand in industrial markets, an order of magnitude higher than those of raw coal. Very promising forms of diversification of the resource economies there may be models of vertical integration and cluster organization of the regional economy.

\section{Material and Methods}

The World market for PVC is one of the most dynamic in the global economy. The main areas of consumption of PVC in the world is the production of rigid and flexible pipes and fittings. About 150 companies in 50 countries today produce PVC. About $70 \%$ of global PVC consumption accounts for the construction industry, where the polymer is an essential component in the process of making different designs. The demand for PVC is in direct proportion to the dynamics of the construction industry.

The highest rates of growth of consumption volume are demonstrated by such countries as China, India, Russia, Middle East countries. The next five years they will have a key influence on the global market [1]. The share of Russia in world volume of production of PVC reaches a $1.6 \%$, share in global consumption $-2.7 \%$. Currently, the PVC market in Russia is totally import-dependent, and the main supply comes from the United States and China. Since 2006, Russia is the main consumer of Chinese PVC in the world. $n$ the structure of export of Chinese PVC Russia plays a key role: in 2014 - 2015, its share was about $50 \%$, and in 2016-2017 the trend has not changed. To reverse this situation is possible only through the creation of the own production, on the basis of carbide and ethylene technology. However, given the experience of the enterprises of the coal and chemical industries of the Kuznetsk basin, coal companies, taking into account the presence of scientific bases in the region, this task at the present stage can be completely solved.

Up to the present time, $74 \%$ of global capacity is represented by the countries of Asia, including China (67\%) and India (2\%). Europe accounts for $11 \%$,Middle East $-6 \%$, other countries - 9\%. The Eastern and Western Europe together account for about $26 \%$ of world production of PVC [2]. Since the beginning of the century the centre of production and consumption of PVC has moved to China, where, according to some sources, in the period 2005-2010 production capacity grew annually by almost $10 \%$, and according to the other (China Chlorine-Alkali Industry Ass.), over the last decade the production of PVC in China grew by 3-4 times. Really, when you consider that in 2004, China produced just over 5 million tonnes (in $2006-11$ million tons), and now $2 / 3$ of the capacities are concentrat- 
ed in China, we can say that the production of PVC in this country has taken very serious steps. Today, Chinese PVC production is estimated to be 15-20 million tons. It should be noted that the basis for PVC production in China is carbide technology, according to which currently China produces $70-80 \%$ of PVC [3]. This is due to the cheap cost of raw coal and electricity produced in the North-Western provinces. Chinese companies follow the way of formation of clusters consisting of enterprises in the coal industry, energy production, chemicals, processing of raw materials into finished products with high added value.

In the Russian market of PVC are clearly visible the conditions and limits that stimulate and restrict the localization of production in Russia - the process that better describes the growth of the industry than the so called "import substitution". The capacity of the domestic market is enough to invest in basic raw materials at the scale of a large plant, but, however, is inadequate for special grades of PVC.

\section{Results and Discussion}

The rapid growth of PVC production in Russia in physical terms in the period from 2012 to 2015 is confirmed by $18 \%$ growth in 2015 compared to the previous 2014 and 1,5 times growth compared to the basic 2012 This fact proves the rapid growth of this sub-sector compared to the whole plastics processing industry, where the annual development rate reached $11.8 \%$ in 2015 .

In continuation of this study highly rational and innovative, in our opinion, is the placement of the PVC production based on vertical integration of the enterprises of the coal industry, enterprises of non-metallic materials, metallurgy and other enterprises of Kuzbass, in particular with leading producers of chemical products in the region, such as JSC "Khimprom" - a potential supplier of chlorine for the production of vinyl chloride monomer.

The production of acetylene, given the resource potential of the Kuzbass and the largest enterprise JSC "Cox", included in industrial metallurgical holding, is possible with the use of three technologies:

-production of acetylene from calcium carbide (carbide),

- production of acetylene from methane extracted from coal seams, the method of electrocracking or oxidative pyrolysis

- production of acetylene from coke oven gas obtained in the process of main production at JSC "Cox" and containing 27\% methane and 55\% of hydrogen.

Carbide acetylene can compete with ethylene as a raw material for the production of vinyl chloride, if its value does not exceed the cost of ethylene by more than $40 \%$. If the cost of the acetylene produced from methane is quite low, this method will be competitive [4].

In practice, the most appropriate method of production of acetylene is the combined method on the basis of coke oven gas and methane derived from coal beds and delivered in liquefied form to the company. Currently PJSC "Gazprom" together with LLC "Gazprom Mining Kuznetsk" develop a project for production of liquefied methane extraction sites. Thus, this part of the process is quite realizable in practice.

On the basis of the method of obtaining vinyl chloride by acetylene hydrochloride lies the catalytic reaction occurring with high heat. Hydrogen chloride has to come from the Kemerovo enterprise JSC "Khimprom". This method is characterized by the simple technological design process, low investments, high selectivity to vinyl chloride, but the method has not found wide industrial application due to the high cost of acetylene. Hydrochloride process of acetylene is usually carried out in the presence of mercuric chloride, applied in the amount of $10-15 \%$ on activated carbon, in a stationary layer of catalyst at $425-535 \mathrm{~K}$ and a pressure of $0.2-1.5 \mathrm{MPa}$. The degree of conversion of acetylene is $98.5 \%$ with a selectivity to vinyl chloride of $98 \%$ [4]. 
Polymerization occurs in the droplets of vinyl chloride. In the end it is possible to obtain porous microspheres. Production is fully automated, the polymerization is carried out in reactors whose volume exceeds 200 cubic meters [5].

After completion of the polymerization degree of vinyl chloride, which by this time has reacted, reaches up to 90 percent. Items that were not used are removed, while PVC itself is sifted and dried with hot air, then there is packaging. Polyvinyl chloride in the last step is converted to vinyl or plastic [6]. Feature of plasticity is the presence of stabilizers.

On their nature and amount largely depends the workability (processability) of the compositions of PVC and lifetime of the final product. Indirect characteristics of the selection of these additives is such characteristics of the plastic as the thermal stability, allowing to carry out the technological process of production of the final product in a wider temperature range [6].

Main additives in PVC upon receiving the plastic forms are calcium stearate and flame retardants, manufactured at the Russian enterprises [5]. To reduce the flammability of PVC, the introduction of the plasticized hydroxides of aluminium or magnesium is possible [6]. Suspension PVC is produced in the form of a homogeneous white powder with a bulk density $450-700 \mathrm{~kg} / \mathrm{m} 3$. An important element of the process is the production of powder PVC products having a higher commodity value, and used in various industries. The most suitable is the production of sheets and films of PVC pipes and profiles [6].

Production of PVC is possible on the basis of industrial cooperation and vertical integration of enterprises of Kuzbass within the frames of the functioning of the coal chemical cluster. In the production chain should be involved, given the characteristics of the production the following companies: coal companies, coal mining coke coal comprising the process enriching enterprises, JSC "Koks", OJSC Khimprom, Kemerovo state district power station and other power generating companies that are part of the Siberian generating company, LLC "Gazprom Mining Kuznetsk." To the chain can be aligned the enterprises of small and average business manufacturing the finished product from the powder (Fig. 1).

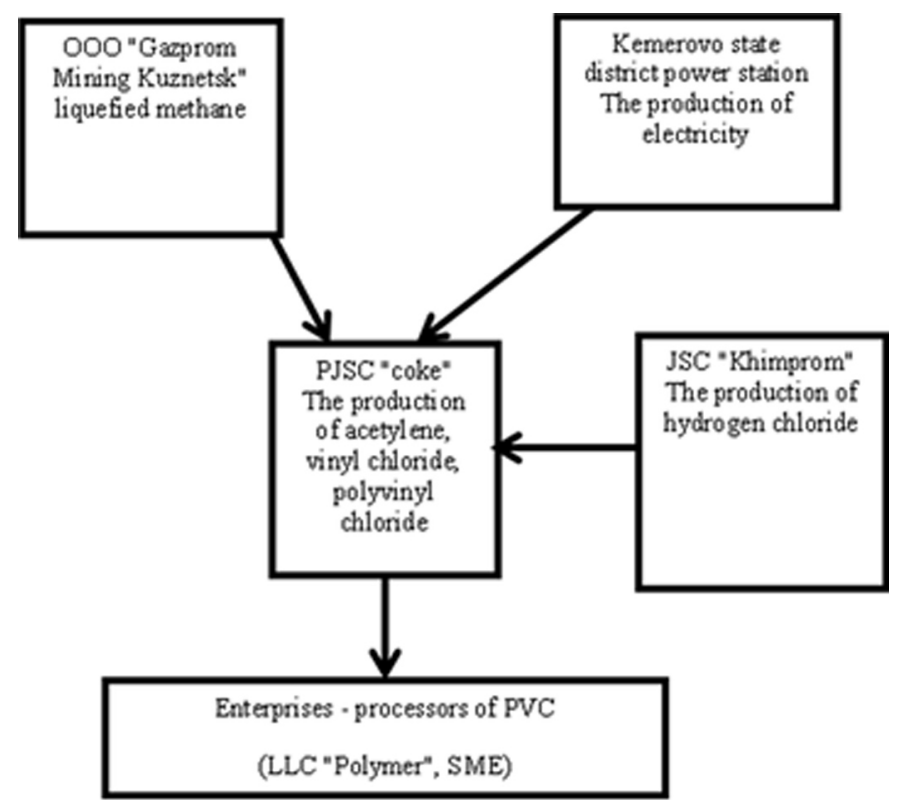

Fig. 1. The generating process PVC production based on vertical integration of enterprises of the Kemerovo region. 
These companies will be involved in the process of creating value added chain for the entire process chain, from extraction process to the finished product (services) on the market. The production of such complex product, like PVC, will allow to create downstream value chains that appear around the production and export of innovative, high-tech final goods and services produced by the enterprises of the Kuznetsk basin [7].

The development of coal chemical cluster engaged in extraction and processing of raw materials will generate value-added chain in the Kuzbass, which may be a catalyst of process of economic diversification of the economy of the old coal region and individual industries of the Kemerovo region [8-10].

\section{Conclusions}

It is established that the organization of production of polyvinyl chloride on the basis of production of PJSC "coke," coal enriching plants using coal chemical technology can be a promising growth point for the economy of Kuzbass, part of a data bank for promising investment projects for potential and existing market area businesses. This will provide some sectors of the economy of Kuzbass with such important materials as PVC, to reduce its import dependence, diversify the production of coal, chemical and metallurgical enterprises, broaden the product structure with the introduction of the polymer and the export opportunities of the region and thus to improve the economic performance of the business, to increase tax revenues to the budgets of different levels. Rational and optimal choice of aggregate technology value chains will allow ensuring the sustainable development of the region's economy to ensure its competitiveness relative to the new coal Russian Far Eastern regions on the principles of rational use of the subsoil

\section{References}

1. M. Schiller, PVC Additives: Performance, Chemistry, Developments \& sustainability (London: Hansen Gardner Publications, 2015)

2. M. Biron, Industrial applications of renewable Plastics: Environmental, Technological \& Economic advances (Plastics Design Library) (Chicago: William Andrews, 2016)

3. Ye Liping, Life cycle assessment of polyvinyl chloride production \& it's recyclability in China (Beijing, HDGT, 2010)

4. S. A Pazur, Plast. Eng. 34:1, 62 (1978)

5. C. Chauffoureaux, C. Dehennau, Flow and thermal stability of Rigid PVC (New York, November, 1977)

6. P. Rice, U. Adam, Developments in PVC Production and Processing (London, Chem,1977)

7. T. J. Sturgeon, IDS Bull, 32:3, 9-18 (2001)

8. S. Zhironkin, M. Gasanov, G. Barysheva, K. Kolotov, O. Zhironkina, E3S Web of Conf., 15, 03012 (2017)

9. F. Agafonov, A. Genin, O. Kalinina, O. Brel, O. Zhironkina, E3S Web of Conf., 15, 04011 (2017)

10. M. Erkayaoğlu, N. Demirel, J. Env. Man., 174, 1-6 (2016) 
